\title{
Effects of dietary leucine and phenylalanine on pancreas development, enzyme activity, and relative gene expression in milk-fed Holstein dairy calves
}

\author{
Y. C. Cao, ${ }^{*}$ X. J. Yang, ${ }^{*}$ L. Guo, ${ }^{*}$ C. Zheng, ${ }^{*}$ D. D. Wang, ${ }^{*}$ C. J. Cai, ${ }^{*}$ S. M. Liu,† and J. H. Yao* ${ }^{* 1}$ \\ ${ }^{*}$ College of Animal Science and Technology, Northwest A\&F University, Yangling, Shaanxi 712100, P. R. China \\ †School of Agriculture and Environment, the University of Western Australia, Crawley, Australia 6009
}

\begin{abstract}
This study aimed to investigate the effect of dietary supplementation with leucine and phenylalanine on pancreas development, enzyme activity, and related gene expression in male Holstein calves. Twenty male Holstein calves [1 d of age, $38 \pm 3 \mathrm{~kg}$ of body weight $(\mathrm{BW})$ ] were randomly assigned to 1 of the following 4 treatment groups with 5 calves in each group: control, leucine supplementation (1.435 g/L of milk), phenylalanine supplementation $(0.725 \mathrm{~g} / \mathrm{L}$ of milk), and leucine and phenylalanine $(1.435+0.725 \mathrm{~g} / \mathrm{L}$ of milk $)$. The diets were made isonitrogenous with the inclusion of alanine in each respective treatment. The feeding trial lasted for $8 \mathrm{wk}$, including $1 \mathrm{wk}$ for adaption and $7 \mathrm{wk}$ for the feeding experiment. Leucine tended to increase the concentration of total pancreatic protein $(\mathrm{mg} / \mathrm{kg}$ of $\mathrm{BW})$. Phenylalanine increased the concentrations of plasma insulin, cholecystokinin, and pancreatic DNA (mg/g) and the expression of trypsin gene but decreased the pancreatic protein:DNA ratio and tended to decrease the pancreas weight $(\mathrm{g} / \mathrm{kg}$ of $\mathrm{BW})$. No differences were observed in total pancreatic DNA $(\mathrm{mg} /$ pancreas and $\mathrm{mg} / \mathrm{kg}$ of $\mathrm{BW}$ ), pancreatic protein ( $\mathrm{mg} /$ pancreas), or activities of $\alpha$-amylase, trypsin, and lipase. The relative expression levels of the genes encoding $\alpha$-amylase and lipase did not differ among the 4 groups. The supplementation of both leucine and phenylalanine showed an interaction on the pancreas weight ( $\mathrm{g}$ and $\mathrm{g} / \mathrm{kg}$ of BW) and a tendency of an interaction on the pancreatic protein concentration $(\mathrm{mg} / \mathrm{g}$ of pancreas and $\mathrm{mg} /$ $\mathrm{kg}$ of BW) and the plasma glucose concentration. Leucine tended to increase the size of the pancreatic cells, whereas phenylalanine tended to increase the number of pancreatic cells. However, neither AA affected the activities of the pancreatic enzymes of the calves. These results indicate that leucine and phenylalanine supple-
\end{abstract}

Received October 12, 2017.

Accepted January 4, 2018.

${ }^{1}$ Corresponding author: yaojunhu2004@sohu.com mentation in milk-fed Holstein calves differentially affect pancreatic growth and development.

Key words: calf, leucine, pancreas, phenylalanine

\section{INTRODUCTION}

The composition and content of dietary carbohydrates are key factors affecting rumen fermentation and the health and productivity of ruminants. To achieve the full genetic potential of lactating cows, diets rich in starch could be fed to increase milk production (Herrera-Saldana et al., 1990). The starch is first degraded in the rumen by amylolytic microbes to produce VFA, predominantly acetate, propionate, and butyrate, which are absorbed into the rumen wall. In ruminants, starch that resists microbial enzymatic degradation in the upper gut sections (i.e., forestomachs) may be termed bypass starch, undegradable starch, or ruminally resistant starch. More precisely, ruminally resistant starch is expected to resist degradation mechanisms in the rumen and be digested in the small intestine (Deckardt et al., 2013). About 18 to $42 \%$ of the starch bypasses rumen degradation and enters the small intestine (Owens et al., 1986), which could supply about $30 \%$ of total glucose needs (Huntington, 1997). Pancreatic $\alpha$-amylase mediates the hydrolysis of rumen bypass starch to oligosaccharides or membranebound intestinal $\alpha$-glucosidases, which hydrolyze these oligosaccharides to glucose in the small intestines. The released glucose is absorbed by the intestinal epithelial cells, providing the most important source of exogenous glucose for ruminants. The energy efficiency of starch in the small intestine is $42 \%$ higher than that in the rumen (Huntington et al., 2006). However, the digestibility of the small intestine for starch in dairy cows is on average 35 to $60 \%$ (Harmon et al., 2004), and thus some of the rumen bypass starch may not be digested, resulting in energy used inefficiently and health risks (Gressley et al., 2011). Zinn et al. (2002) revealed that the increase in digestibility depends on disruption of the protective protein matrix surrounding the starch 
granules rather than simply increasing starch solubility. Several studies have shown that insufficient secretion of pancreatic $\alpha$-amylase is the limiting factor in the utilization of rumen bypass starch (Swanson et al., 2002; Harmon et al., 2004). Therefore, increasing the secretion of pancreatic $\alpha$-amylase in dairy cows could be an approach to improve the energy supply and production performance of high-yielding dairy cows.

The pancreas is an important gland in the animal digestive system. Internal and external pancreatic secretions are essential for nutrient digestion and the regulation of several physiological processes. The pancreatic juice secreted by the pancreas is rich in bicarbonate and contains several types of digestive enzymes, including trypsin, pancreatic lipase, and pancreatic amylase, all of which are important hydrolases and play important roles in digestion and absorption (Rinderknecht et al., 1983). The secretion of pancreatic juice is affected by many factors, such as the age of the animal (Jiang et al., 2013), insulin (Baile et al., 1969), cholecystokinin (Owyang, 1994), dietary protein (Hara et al., 1996), and energy levels (de Dios et al., 1988). The effects of dietary protein and AA on the synthesis and secretion of trypsin have attracted much research interests. Richards et al. (2002) showed that in growing steers (initial BW $=379 \mathrm{~kg}$ ) infused with starch $(1,042 \mathrm{~g} / \mathrm{d}$ ) into the small intestine, the concentration of pancreatic $\alpha$-amylase linearly increased in a dose-responsive manner to the amounts of infused casein $(0,50,100$, 150, and $200 \mathrm{~g} / \mathrm{d}$ ). Greater quantities of starch disappeared with increased casein infusion, and the infusion of $200 \mathrm{~g} / \mathrm{d}$ of casein increased small intestinal starch disappearance by $226 \mathrm{~g} / \mathrm{d}$ over the control. Swanson et al. (2008) obtained similar results by increasing the rumen bypass of soybean meal in yearling beef steers (initial BW $=510 \mathrm{~kg}$ ). The studies of Liao et al. (2009) in Angus steers (initial BW $=260 \mathrm{~kg}$ ) and Swanson et al. (2004) in Angus steers (initial BW $=290 \mathrm{~kg}$ ) also revealed a positive dynamic relationship between the supply of protein and the secretion of pancreatic amylase. These authors also observed that a change in the ratio of the EAA to starch in the small intestine could change pancreatic amylase secretion. By infusing casein, EAA, NEAA, and glutamate into the duodenum, Brake et al. (2014) found that casein and EAA increased the secretion of pancreatic amylase without affecting the starch digestibility in the small intestine, whereas NEAA and glutamate increased the starch digestibility (steer initial BW $=259 \mathrm{~kg}$ ). Yu et al. (2014) showed that both protein and AA could influence the activities of pancreatic enzymes and the expression of their genes in yearling ewes (initial BW $=297 \mathrm{~kg}$ ) by altering pancreas development.
Amino acids traditionally were classified as nutritionally essential or nonessential for animals and humans based on nitrogen balance and growth (Wu, 2010). A key element of this classification is that all NEAA are assumed to be synthesized adequately in the body to meet the needs for protein synthesis (Wu, 2013). Therefore, $\mathrm{Wu}$ (2010) proposed a concept of functional AA, which is defined as those AA that participate in and regulate key metabolic pathways to improve health, survival, growth, development, lactation, and reproduction of the organisms. Leucine can regulate protein synthesis and catabolism in animals by activating the mammalian target of rapamycin pathway (Boultwood et al., 2013; Kim et al., 2013). Phenylalanine is an aromatic AA that can promote the secretion of cholecystokinin (CCK) through the calcium-sensing receptors (Liou et al., 2011). Cholecystokinin can promote the synthesis of pancreatic amylase, trypsin, and trypsinogen, stimulate the release of these pancreatic enzymes, and enhance their activities. Duodenal infusions of phenylalanine (Yu et al., 2013) and leucine (Liu et al., 2015) play a role in regulating the secretion of pancreatic $\alpha$-amylase.

The above studies showed that AA play a regulatory role in pancreas secretion and the gene expression of pancreatic enzymes at both transcriptional and translational levels. We thus hypothesized that supplementation of leucine or phenylalanine further strengthens their roles in the regulation of pancreatic metabolism, leading to an increment of exogenous enzyme production. We noted that the aforementioned studies used cannulated animals to infuse the substrates via the cannula to avoid ruminal degradation, and influences of the surgery preparation on the results remain undefined. Therefore, the present study investigated the effects of supplemental leucine and phenylalanine on pancreas development, enzymatic activity, and transcriptional regulation in milk-fed Holstein dairy calves without any surgical preparation.

\section{MATERIALS AND METHODS}

The use of the animals and experimental protocols was approved by the Animal Care and Use Committee of the College of Animal Science and Technology, the Northwest A\&F University (Yangling, Shaanxi, China).

\section{Animals, Experimental Design, and Diets}

Twenty male Holstein calves (1 d of age, $38 \pm 3 \mathrm{~kg}$ of BW) were used in this study. Within $1 \mathrm{~h}$ after birth, each calf was fed $4.0 \mathrm{~L}$ of colostrum with an IgG concentration $>50 \mathrm{~g} / \mathrm{L}$. The calves were randomly assigned 
to 4 groups (5 calves/group). The calves in the control group received pasteurized milk only, whereas the calves in the treatment groups were fed milk supplemented with leucine (1.435 g/L of milk), phenylalanine (0.725 $\mathrm{g} / \mathrm{L})$, or both AA mixed (1.435 g of leucine/L and 0.725 $\mathrm{g}$ of phenylalanine/L), which were dissolved in the milk. The milk fed to all the groups was made isonitrogenous by adding alanine $(1.366,0.391,0.975$, and $0 \mathrm{~g} / \mathrm{L}$ of milk for control, leucine, phenylalanine, and mixed treatments, respectively). The doses of leucine and phenylalanine for the experimental groups were based on the results of Yu et al. (2013) and Liu et al. (2015). The milk was sampled weekly and stored at $-20^{\circ} \mathrm{C}$, and the samples were pooled. The AA composition of the milk sample was determined by Evonik Nutrition and Care GmbH (Beijing, China) using ion-exchange chromatography with postcolumn derivatization with ninhydrin. Milk proteins were hydrolyzed with $6 \mathrm{M} \mathrm{HCl}$ for $24 \mathrm{~h}$ at $110^{\circ} \mathrm{C}$, and free $\mathrm{AA}$ were quantified by measuring the absorption of reaction products with ninhydrin at $570 \mathrm{~nm}$ against their standards (Sadri et al., 2017). The mean concentrations are shown in Table 1. The amount of the AA supplemented (including the amounts of alanine added) was about $42 \%$ of the total AA present in the milk. The calves were fed individually.

The feeding trial lasted for $8 \mathrm{wk}$, with the first week for the adaptation. During the first week, the calves were manually bottle fed $3 \mathrm{~L}$ of milk twice daily. During the adaption period, AA supplementation was increased $20 \%$ daily until it reached $100 \%$ of the target supplementation on the sixth day. From wk 2 to 3, the calves were manually bucket fed $3.5 \mathrm{~L}$ of milk twice daily, and from wk 4 to 8 they were fed 4 L of milk twice daily. The milk offered to the calves was fully consumed without any refusal.

From the beginning of the third week, a starter feed was provided twice daily. The amount of feed offered to each calf was $210 \mathrm{~g} / \mathrm{d}$ in wk 3 and gradually increased to $1,800 \mathrm{~g} / \mathrm{d}$ in wk 8 to ensure that all calves consumed the feed without any refusal. The calves had free access to fresh drinking water. The commercial starter was provided by Purina (Purina Mills Start and Grow Sunfresh; St. Louis, MO). The ingredients and nutrient composition of the starter are shown in Table 2.

\section{Sample Collection and Analysis}

On the last day of wk 8, 20 calves were slaughtered after $16 \mathrm{~h}$ of fasting. The animals were killed by bleeding the jugular vein by a registered veterinarian. The slaughtering procedure proceeded as following: 4 calves/d, 1 from each treatment, sequentially ceased feeding in 1-h intervals, and after $16 \mathrm{~h}$ of fasting they were slaughtered in the same order. This was to ensure
Table 1. Concentrations $(\mathrm{g} / \mathrm{L})$ of AA in milk fed to calves

\begin{tabular}{lc}
\hline AA & Concentration \\
\hline Arginine & 1.429 \\
Histidine & 0.920 \\
Isoleucine & 1.744 \\
Leucine & 3.432 \\
Lysine & 3.055 \\
Methionine & 0.950 \\
Phenylalanine & 1.731 \\
Threonine & 1.804 \\
Valine & 2.372 \\
Alanine & 1.356 \\
Aspartate & 2.869 \\
Cysteine & 0.358 \\
Glutamate & 7.605 \\
Tyrosine & 1.846 \\
Glycine & 0.838 \\
Serine & 2.260 \\
Proline & 6.458 \\
\hline
\end{tabular}

that each animal was fasted for the same period of 16 h. All 20 calves were slaughtered over $5 \mathrm{~d}$, with random orders of 4 treatments on each day. Before slaughter, 10 $\mathrm{mL}$ of blood was collected from the jugular vein into a heparinized syringe and immediately centrifuged at $2,500 \times g$ for $15 \mathrm{~min}$ at $4^{\circ} \mathrm{C}$. Then, plasma was collected into a $2-\mathrm{mL}$ centrifuge tube. Aprotinin was added at a final concentration of $10,000 \mathrm{IU} / \mathrm{mL}$. The plasma samples were stored at $-80^{\circ} \mathrm{C}$ until analysis.

Plasma glucose was determined on the day of sampling using the glucose oxidase-peroxidase assay kit (Jiancheng, Nanjing, China) and a Synergy HT Multifunctional Microplate Reader (Power Wave XS2, BioTek, Winooski, VT). Plasma urea nitrogen, total

Table 2. Nutrient levels of the starter ${ }^{1}$ fed to calves (\% DM)

\begin{tabular}{lc}
\hline Item & Content, $\%$ \\
\hline DM & 87.06 \\
CP & 20.01 \\
Crude ash & 15.47 \\
Starch & 38.79 \\
NDF & 12.20 \\
ADF & 6.20 \\
Calcium & 0.70 \\
Total phosphorus & 0.38 \\
\hline
\end{tabular}

${ }^{1}$ The starter was purchased from Purina Co. (St. Louis, MO). It contained corn, soybean meal, wheat bran, sugar cane molasses, calcium hydrophosphate, stone powder, salt, L-lysine, vitamin $\mathrm{A}$, vitamin $\mathrm{D}_{3}$, vitamin $\mathrm{E}$, copper sulfate, and ferrous sulfate. The AOAC International (1999) methods were used to determine the DM (method 930.5), CP $(\mathrm{N} \times 6.25$; method 984.13), ash (method 942.05), calcium (method 927.02), and phosphorus (method 965.17) contents in the starter. The contents of NDF and ADF were sequentially determined according to the methods described by Van Soest et al. (1991), with heat-stable $\alpha$-amylase (A3306, Sigma-Aldrich, St. Louis, MO) and sodium sulfite being used in the NDF procedure (inclusive of residual ash). The starch content was determined using an enzymatic method ( $\alpha$-amylase and amyloglucosidase) implemented in a commercial starch analysis kit (Megazyme International Ireland Ltd., Bray, Ireland). All analyses were performed in our laboratory. 
Table 3. The PCR primers used to amplify genes encoding $\alpha$-amylase, trypsin, and lipase

\begin{tabular}{lll}
\hline Item & Forward primer & Reverse primer \\
\hline$\alpha$-Amylase & GAAATGGCCGTGTGACAGAATTTA & ACAAAGACAAGTGCCCTGTCAGAA \\
Trypsin & TGTCTGCGGCTCACTGCTAC & GCTGGGATGGACGATACTCTTG \\
Lipase & GTGGAAGCAAATGATGGACAAG & TGGGTTGAGGGTGAGCAGA \\
$18 \mathrm{~S}$ rRNA & ACCCATTCGAACGTCTGCCCTATT & TCCTTGGATGTGGTAGCCGTTTCT \\
\hline
\end{tabular}

${ }^{1}$ Housekeeping gene.

protein, albumin, and globulin were determined using commercial kits (Jiancheng). Insulin and CCK were determined using an ELISA kit (Cloud-Clone Corp., Katy, TX). The concentration of AA in plasma was measured by Evonik Nutrition and Care GmbH using ion-exchange chromatography with postcolumn derivatization with ninhydrin. The EAA pool included leucine, phenylalanine, arginine, histidine, isoleucine, lysine, methionine, threonine, and valine; the NEAA pool included alanine, aspartate, cysteine, glutamate, glutamine, glycine, serine, proline, and taurine. Total AA was the sum of EAA and NEAA.

Immediately after slaughter, the pancreas was separated and weighed. Then, a sample $(3-5 \mathrm{~g})$ was taken, frozen in liquid nitrogen, and stored at $-80^{\circ} \mathrm{C}$ for evaluation of the pancreas development later on using the method of Crozier et al. (2008). Another pancreatic tissue sample $(\sim 2 \mathrm{~g})$ was taken and homogenized in a homogenizing solution (containing $5 \mathrm{mM} \mathrm{MgCl} 2$ and $0.1 \%$ Triton $\mathrm{X}-100, \mathrm{vol} / \mathrm{vol}$ ) and sonicated for $15 \mathrm{~s}$. The homogenate was centrifuged at $1,000 \times g$ at $4^{\circ} \mathrm{C}$ for 10 min, and then the supernatant was used for assays of the total protein and enzyme activities. The total protein concentration in the homogenate was determined using a protein detection kit (Jiancheng). The activities of $\alpha$-amylase, trypsin, and lipase in the homogenate were determined using respective assay kits per the manufacturer's instructions without any modification (Jiancheng). The DNA was extracted and then quantified using a DNA quantification kit (Sigma-Aldrich). The total protein content in the pancreatic tissue was calculated against the calibration curve using bovine albumin as the standard. Concentration and content of DNA were used as an index of pancreatic hyperplasia (change in cell number), and protein:DNA ratios were used as indices of pancreatic hypertrophy (change in cell size; Swanson et al., 2008).

The expression levels of pancreatic $\alpha$-amylase, trypsin, and lipase mRNA were determined using real-time quantitative PCR using respective specific primers (Table 3). Between 50 and $100 \mathrm{mg}$ of pancreatic tissue was ground in liquid nitrogen, and the total RNA was isolated using the Animal Tissue Total RNA extraction kit (Tiangen Biotech, Beijing, China). The total RNA concentrations were quantified by absorbance at $260 \mathrm{~nm}$ using a NanoDrop 2000 spectrophotometer (Thermo Fisher Scientific, Waltham, MA), and sample integrity was determined by the ratio of absorbance at $260 \mathrm{~nm}$ to $280 \mathrm{~nm}$, with all samples having a ratio $\geq 1.9$.

Reverse transcription (RT) was performed using the PrimeScript RT reagent kit (TaKaRa Biotechnology Co. Ltd., Dalian, China). Each RT reaction $(20 \mu \mathrm{L}$ total volume) contained $4.0 \mu \mathrm{L}$ of $5 \times$ PrimeScript buffer, $1.0 \mu \mathrm{L}$ of PrimeScript RT enzyme mix I, $1.0 \mu \mathrm{L}$ of oligo dT primer $(50 \mu M), 1.0 \mu \mathrm{L}$ of random 6 mers $(100 \mu M)$, $1.0 \mu \mathrm{L}$ of total RNA, and $12.0 \mu \mathrm{L}$ of RNase-free distilled $\mathrm{H}_{2} \mathrm{O}$. Real-time quantitative PCR was performed using the SYBR Premix Ex TaqTM II kit (TaKaRa Biotechnology Co. Ltd.) to quantify the transcripts of the genes coding for pancreatic $\alpha$-amylase, trypsin, and lipase. The real-time PCR reaction $(25 \mu \mathrm{L}$ total volume) contained $12.5 \mu \mathrm{L}$ of SYBR Premix Ex TaqTM II, $1.0 \mu \mathrm{L}$ of each primer, $1.0 \mu \mathrm{L}$ of cDNA template, and $9.5 \mu \mathrm{L}$ of double-distilled $\mathrm{H}_{2} \mathrm{O}$. The thermal cycles were as follows: initial denaturation at $95^{\circ} \mathrm{C}$ for $5 \mathrm{~min}$; 40 cycles of $95^{\circ} \mathrm{C}$ for $10 \mathrm{~s}, 60^{\circ} \mathrm{C}$ for $30 \mathrm{~s}$, and $72^{\circ} \mathrm{C}$ for $30 \mathrm{~s}$; and a final extension at $72^{\circ} \mathrm{C}$ for $5 \mathrm{~min}$. The amplification efficiency of each gene was validated by constructing a standard curve through serial dilutions of cDNA. All samples were run in triplicate, and $18 \mathrm{~S}$ rRNA (the housekeeping gene) was selected as an endogenous control to normalize the target gene expression (White et al., 2012). The average cycle threshold values were calculated using the $2^{-\Delta \Delta \mathrm{Ct}}$ method (Livak and Schmittgen, 2001).

\section{Statistical Analysis}

The data were analyzed using the MIXED procedure of SAS (version 9.1; SAS Institute Inc., Cary, NC) using the following model:

$$
\mathrm{Y}_{\mathrm{jk}}=\mu+\mathrm{L}_{\mathrm{j}}+\mathrm{P}_{\mathrm{k}}+\mathrm{LP}_{\mathrm{jk}}+\varepsilon_{\mathrm{jk}},
$$

where $Y_{j k}$ is the response variable, $\mu$ is the overall mean, $\mathrm{L}_{\mathrm{j}}$ is the fixed effect of leucine ( $\mathrm{j}=$ with or without), $\mathrm{P}_{\mathrm{k}}$ is the fixed effect of phenylalanine $(\mathrm{k}=$ with or without), $\mathrm{LP}_{\mathrm{jk}}$ is the interaction of leucine and phenylalanine, and $\varepsilon_{\mathrm{jk}}$ is the residual error. The results were reported as the least squares means \pm standard error 
Table 4. Amino acid concentrations in plasma of male Holstein calves fed milk and the starter supplemented with leucine and phenylalanine $(\mathrm{n}=5)$

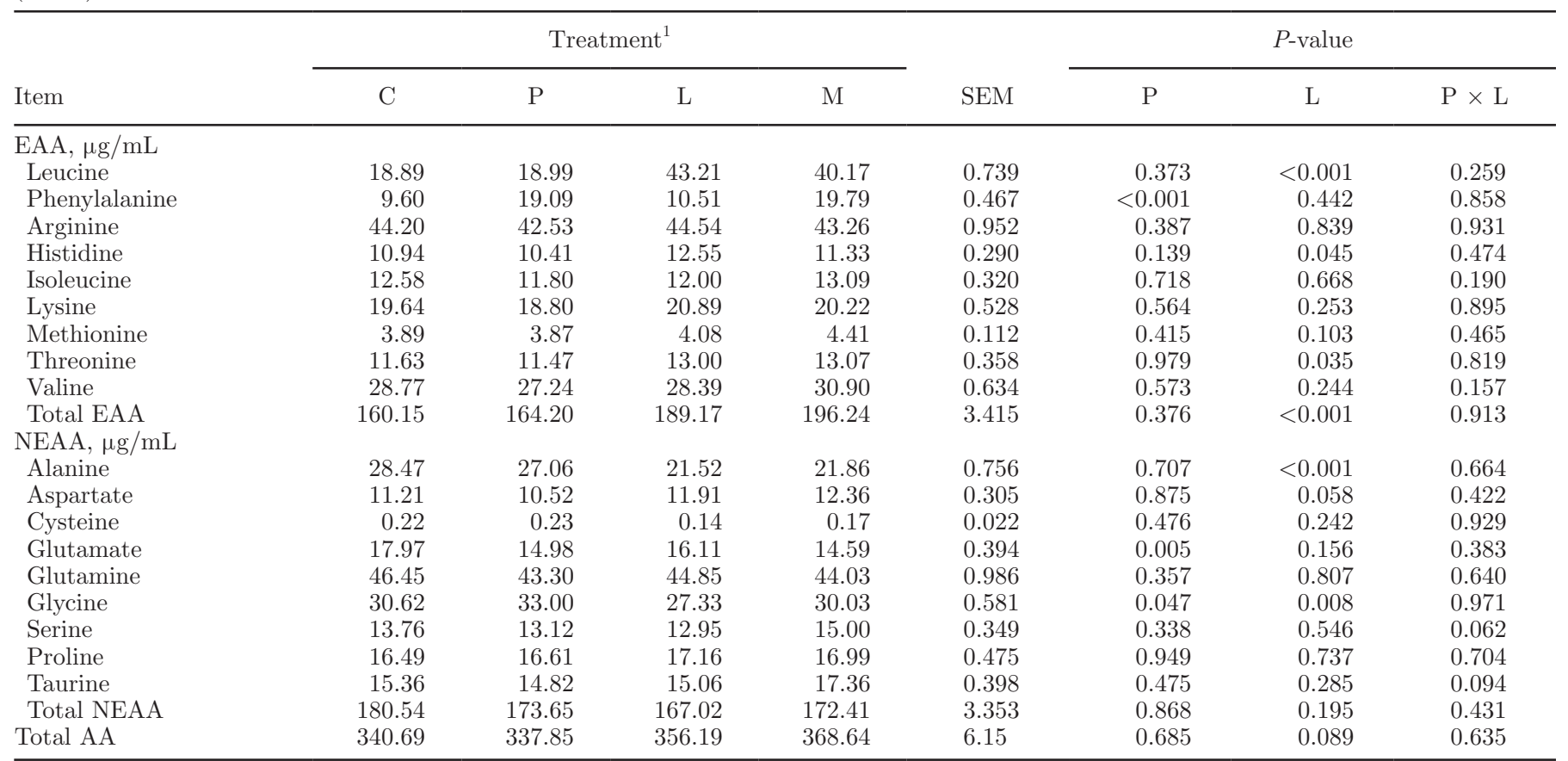

${ }^{1} \mathrm{C}=$ control (pasteurized milk only); $\mathrm{P}=$ milk supplemented with phenylalanine $(0.725 \mathrm{~g} / \mathrm{L}) ; \mathrm{L}=$ milk supplemented with leucine $(1.435 \mathrm{~g} / \mathrm{L}) ;$ $\mathrm{M}=$ milk supplemented with both leucine $(1.435 \mathrm{~g} / \mathrm{L})$ and phenylalanine $(0.725 \mathrm{~g} / \mathrm{L})$.

of the mean, and a treatment difference was declared significant at $P \leq 0.05$ or a trend at $P<0.10$.

\section{RESULTS}

\section{Effects of Leucine and Phenylalanine Supplementation on Plasma AA and Metabolite Concentrations}

Table 4 shows the AA concentrations in plasma upon supplementation of leucine and phenylalanine.
The supplementations with leucine and phenylalanine increased their concentrations in plasma $(P<0.01)$. However, the supplementations had no effects $(P>$ 0.05 ) on total protein, albumin, globulin, glucose, urea nitrogen concentration, and albumin:globulin ratio in plasma (Table 5). Phenylalanine increased the plasma insulin and CCK concentrations $(P<0.05)$. Phenylalanine and leucine showed a tendency of an interaction on plasma glucose concentration $(P=0.058)$, and leucine infusion alone tended to reduce glucose concentration compared with the control.

Table 5. Metabolite concentrations in plasma of male Holstein calves fed milk and the starter supplemented with leucine and phenylalanine $(\mathrm{n}=5)$

\begin{tabular}{|c|c|c|c|c|c|c|c|c|}
\hline \multirow[b]{2}{*}{ Item } & \multicolumn{4}{|c|}{ Treatment $^{1}$} & \multirow[b]{2}{*}{ SEM } & \multicolumn{3}{|c|}{$P$-value } \\
\hline & $\mathrm{C}$ & $\mathrm{P}$ & L & M & & $\mathrm{P}$ & $\mathrm{L}$ & $\mathrm{P} \times \mathrm{L}$ \\
\hline Total protein, $\mathrm{g} / \mathrm{L}$ & 35.03 & 27.88 & 29.65 & 35.86 & 2.624 & 0.929 & 0.808 & 0.222 \\
\hline Albumin, g/L & 21.23 & 17.83 & 20.33 & 23.42 & 1.522 & 0.960 & 0.453 & 0.302 \\
\hline Globin, g/L & 13.80 & 10.05 & 9.33 & 12.44 & 1.648 & 0.925 & 0.756 & 0.314 \\
\hline Albumin/globin & 1.94 & 1.76 & 2.22 & 2.55 & 0.222 & 0.875 & 0.249 & 0.568 \\
\hline Glucose, mmol/L & 2.85 & 2.57 & 2.41 & 2.64 & 0.064 & 0.874 & 0.176 & 0.058 \\
\hline Urea $\mathrm{N}, \mathrm{mmol} / \mathrm{L}$ & 3.53 & 3.05 & 3.38 & 3.24 & 0.202 & 0.453 & 0.967 & 0.685 \\
\hline Insulin, $\mathrm{pg} / \mathrm{mL}$ & 278.74 & 367.89 & 213.35 & 337.04 & 22.374 & 0.039 & 0.308 & 0.708 \\
\hline Cholecystokinin, $\mathrm{pg} / \mathrm{mL}$ & 4.57 & 5.57 & 3.25 & 3.21 & 0.328 & 0.015 & 0.479 & 0.441 \\
\hline
\end{tabular}

${ }^{1} \mathrm{C}=$ control (pasteurized milk only); $\mathrm{P}=$ milk supplemented with phenylalanine $(0.725 \mathrm{~g} / \mathrm{L})$; $\mathrm{L}=$ milk supplemented with leucine $(1.435 \mathrm{~g} / \mathrm{L}) ; \mathrm{M}=$ milk supplemented with both leucine $(1.435 \mathrm{~g} / \mathrm{L})$ and phenylalanine $(0.725 \mathrm{~g} / \mathrm{L})$. 


\section{Effects of Leucine and Phenylalanine Supplementation on Pancreas Development}

No treatment difference $(P>0.05)$ was observed in the BW, pancreatic DNA content $(\mathrm{mg} /$ pancreas and $\mathrm{mg} / \mathrm{kg}$ of BW), or pancreatic protein content $(\mathrm{mg} / \mathrm{pan}$ creas; Table 6). Phenylalanine increased the pancreatic DNA content per gram of pancreas tissue $(P<0.05)$ and decreased the pancreatic protein:DNA ratio $(P<$ $0.05)$, with a tendency to reduce the pancreatic weight per kilogram of BW $(P=0.091)$. Leucine tended to increase the total pancreatic protein content per kilogram of BW $(P=0.068)$. Leucine and phenylalanine showed interactions on the pancreatic weight (both total and per kilogram of BW; $P<0.05)$ and a tendency of an interaction on the pancreatic protein content (both per gram of pancreas tissue, $P=0.063$, and per kilogram of $\mathrm{BW}, P=0.073)$, and phenylalanine alone reduced the pancreatic weight and its protein content.

\section{Effects of Leucine and Phenylalanine Supplementation on Pancreatic Enzyme Activity and mRNA Expression}

Table 7 shows the activities of pancreatic $\alpha$-amylase, trypsin, and lipase in calves upon supplementation of leucine and phenylalanine. The supplementation with either AA, individually or in combination, did not have effects on the activities of pancreatic $\alpha$-amylase, trypsin, or lipase $(P>0.05)$. As shown in Table 7 , leucine and phenylalanine had no effect on the relative expression levels of $\alpha$-amylase and lipase genes $(P>0.05)$, but phenylalanine increased the relative expression of trypsin gene $(P<0.05)$. No interaction between leucine and phenylalanine was observed on the activity or the expression levels of pancreatic $\alpha$-amylase, trypsin, or lipase $(P>0.05)$.

\section{DISCUSSION}

The low starch digestibility in the small intestine in dairy cows is a factor that could restrict high production performance. Starch is a significant source of energy in high-concentrate diets for high-yielding dairy cows (NRC, 2001), but if dietary starch content is too high, its rapid degradation in the rumen may induce various metabolic diseases such as rumen acidosis. Many factors (e.g., starch form, quality, processing) affect starch digestibility in ruminant diets. For example, processing grains by application of various combinations of heat, moisture, time, and mechanical action could increase digestibility of starch by providing an opportunity for bacterial attachment to starch granules (Huntington, 1997). Owens et al. (1986) provide comprehensive summaries of the effects of grain source and processing methods on the site and extent of digestibility of starch. Energy efficiency of the starch utilization in the rumen of ruminants is lower than that in the small intestine by $42 \%$ (Yu et al., 2013). The starch that bypasses degradation in the rumen and enters the small intestine accounted for 35 to $50 \%$ of the total intake of starch, but the digestibility of the rumen bypass starch in the small intestine was only 35 to $60 \%$ (Harmon, 2009). Therefore, improvement in the digestibility of starch in the small intestine, thereby improving the production performance of ruminants, is important, especially for improving the feed conversion efficiency. The starch, protein, and fat entering the small intestine must first

Table 6. Pancreatic weight and contents of DNA and protein in male Holstein calves fed milk and the starter supplemented with leucine and phenylalanine $(\mathrm{n}=5)$

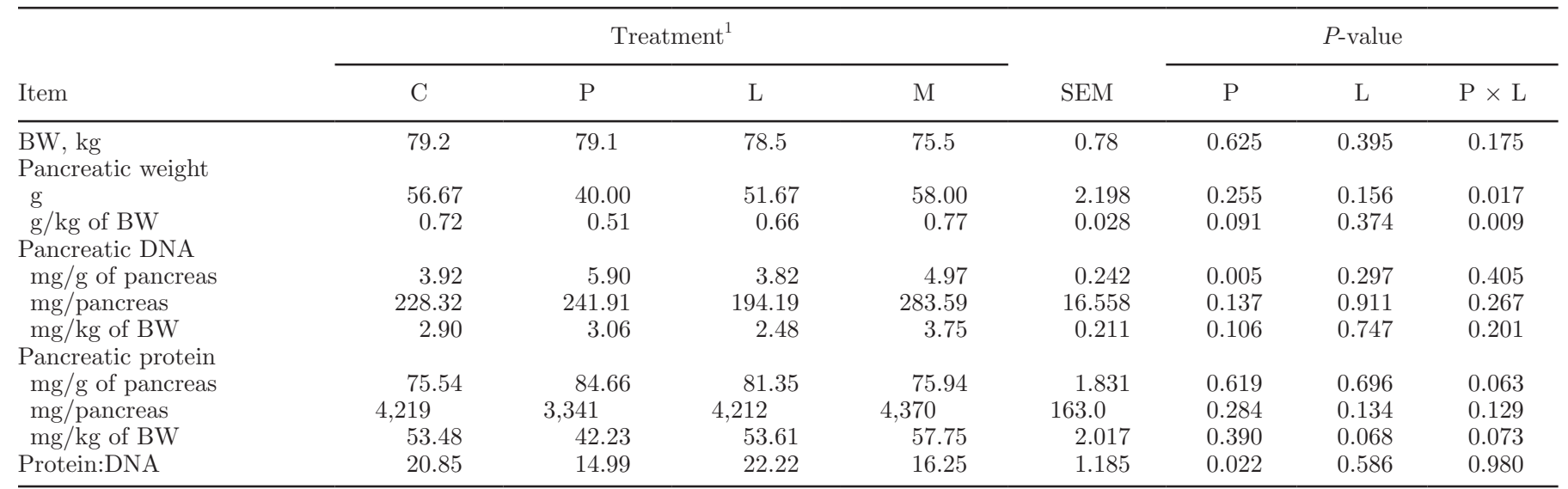

${ }^{1} \mathrm{C}=$ control (pasteurized milk only); $\mathrm{P}=$ milk supplemented with phenylalanine $(0.725 \mathrm{~g} / \mathrm{L}) ; \mathrm{L}=$ milk supplemented with leucine $(1.435 \mathrm{~g} / \mathrm{L})$; $\mathrm{M}=$ milk supplemented with both leucine $(1.435 \mathrm{~g} / \mathrm{L})$ and phenylalanine $(0.725 \mathrm{~g} / \mathrm{L})$. 
Table 7. Activity of $\alpha$-amylase, trypsin, and lipase and the expressions of their genes in the pancreas of male Holstein calves fed milk supplemented with leucine and phenylalanine $(\mathrm{n}=5)$

\begin{tabular}{|c|c|c|c|c|c|c|c|c|}
\hline \multirow[b]{2}{*}{ Item } & \multicolumn{4}{|c|}{ Treatment $^{1}$} & \multirow[b]{2}{*}{ SEM } & \multicolumn{3}{|c|}{$P$-value } \\
\hline & $\mathrm{C}$ & $\mathrm{P}$ & $\mathrm{L}$ & M & & $\mathrm{P}$ & $\mathrm{L}$ & $\mathrm{P} \times \mathrm{L}$ \\
\hline$\alpha$-Amylase & 297.24 & 387.35 & 248.66 & 257.80 & 25.45 & 0.098 & 0.343 & 0.437 \\
\hline Trypsin & 243.99 & 208.65 & 251.39 & 290.18 & 11.93 & 0.081 & 0.943 & 0.140 \\
\hline Lipase & 2,327 & 2,613 & 2,253 & 3,215 & 187.04 & 0.490 & 0.115 & 0.380 \\
\hline \multicolumn{9}{|c|}{ Gene expression ${ }^{2}$} \\
\hline Lipase & 1.41 & 0.76 & 1.08 & 1.08 & 0.237 & 0.501 & 0.983 & 0.498 \\
\hline
\end{tabular}

${ }^{1} \mathrm{C}=$ control (pasteurized milk only); $\mathrm{P}=$ milk supplemented with phenylalanine $(0.725 \mathrm{~g} / \mathrm{L}) ; \mathrm{L}=$ milk supplemented with leucine $(1.435 \mathrm{~g} / \mathrm{L}) ;$ $\mathrm{M}=$ milk supplemented with both leucine $(1.435 \mathrm{~g} / \mathrm{L})$ and phenylalanine $(0.725 \mathrm{~g} / \mathrm{L})$.

${ }^{2}$ Fold change relative to $18 \mathrm{~S}$ rRNA.

be digested (or hydrolyzed) into their monomers (i.e., glucose, AA, and fatty acids, respectively) before they can be absorbed. During the digestion process a variety of enzymes are secreted by the pancreas, including pancreatic $\alpha$-amylase, trypsin, and lipase. Studies have shown that the insufficient secretion of pancreatic $\alpha$-amylase is considered a factor limiting the starch digestion in the small intestine of ruminants (Owens et al., 1986; Harmon, 2009; Brake et al., 2014; Liu et al., 2015). Therefore, research on the pancreas has been focused on enhancing the synthesis and secretion of its digestive enzymes.

The protein synthesis of each pancreatic enzyme (e.g., $\alpha$-amylase, trypsin, and lipase) in preruminant calves is specifically regulated, and the changes of the levels of mRNA specific for these enzymes appear unspecific with the age of animals (Zabielski et al., 1999). To understand possible regulatory mechanisms of individual functional AA rather than changes of overall dietary protein levels, we used the esophageal groove reflex, which exists in suckling calves, to investigate the effects of leucine and phenylalanine on the development of the pancreas in dairy calves, and both AA were dissolved in the milk to feed to the calves. In milk-fed calves (preruminant), liquid feeds (whole milk or milk substitute diet) usually directly enter the abomasum. Hence, leucine and phenylalanine added in the milk can be directly absorbed in the intestine of calves. This was supported by the increments of leucine and phenylalanine concentrations in plasma of the calves, and we anticipated that the increased supplies of leucine and phenylalanine would have an influence on pancreas development, enzyme activity, and relative gene expression in milk-fed calves in this study.

Cholecystokinin is a class of peptides secreted by intestinal mucosal I cells, and it is formed from procholecystokinin (Nilaweera et al., 2010). Cholecystoki- nin is a potent stimulant of the synthesis and release of pancreatic enzymes, and it regulates the pancreatic enzyme secretion by directly acting on the animal acinar cells or by stimulating the vagal nerve (Murphy et al., 2008). Phenylalanine can effectively stimulate the release of CCK through calcium-sensitive receptors (Ballinger and Clark, 1994). The study of $\mathrm{Yu}$ et al. (2013) on dairy goats found that a duodenal infusion of phenylalanine could promote the secretion of pancreatic enzymes by increasing the CCK concentration in the blood. It was noted in this study that plasma CCK was increased by phenylalanine but decreased by leucine, supplemented either alone or with phenylalanine. The promoting effect of phenylalanine on CCK is consistent with the findings of the previous study (Yu et al., 2013), supporting the stimulatory effect of phenylalanine on CCK.

Insulin is a protein hormone that is secreted by the pancreatic islet $\beta$-cells, and its secretion is stimulated by endogenous or exogenous substances such as glucose, lactose, ribose, arginine, and glucagon (Ensafi et al., 2015). This hormone can reduce the blood sugar in animals. This study shows that leucine had no significant effect on plasma insulin level. This is consistent with the findings of Sans et al. (2006), who showed that leucine had no significant effect on plasma insulin. Hashimoto and Hara (2004) also indicated that after receiving a leucine-rich diet for $7 \mathrm{~d}$, mice decreased the secretion of pancreatic $\alpha$-amylase while maintaining the insulin content in the blood. These results differ from reports by Xu et al. (2001) and Yang et al. (2015), who found stimulatory effects of leucine on insulin, possibly because the sustained high concentration of leucine in the blood increased the level of hypoxia-inducing factor $1-\alpha$ in pancreatic cells by activating the mammalian target of rapamycin $\mathrm{C} 1$ pathway, thereby inhibiting the differentiation of pancreatic endocrine precursor cells 
into islet $\beta$-cells (Rachdi et al., 2012). The results of this study also showed that phenylalanine alone could significantly increase the concentration of plasma insulin, mainly because CCK can enhance the insulin secretion. This result is in accordance with Rasmussen et al. (1990), who revealed that CCK can act synergistically through 2 functional classes of neurohumoral agonists (gastric inhibitory polypeptide and glucagonlike peptide 1 activate adenylate cyclase) to enhance insulin secretion.

The weight of the pancreas and the pancreas index can reflect the function of the body to a certain extent (Swanson et al., 2002, 2008; Yu et al., 2013). Swanson et al. (2002) found that postrumen infusion of casein enhanced the pancreatic $\alpha$-amylase and trypsin activities in weaning calves as a result of increased pancreatic size. However, Yu et al. (2013) found that duodenal infusion of phenylalanine to adult goats did not alter the size of the pancreas in goats but rather increased the total $\alpha$-amylase activity by increasing the $\alpha$-amylase protein concentration. In the present study, the supplementation of phenylalanine alone in milk tended to decrease the weight of the pancreas but did not affect the protein concentration; in addition, the activity of $\alpha$-amylase tended to be higher and trypsin activity tended to be lower, and the relative expression of trypsin gene was significantly higher. This result is not consistent with the findings of the previous studies. In Swanson et al. (2002), the infused casein in calves increased the small intestinal protein flow that increased pancreatic weight and thus total pancreatic $\alpha$-amylase and trypsin activity, the effect of which might differ from that by infusion of a single AA. This premise is consistent with the notion that different AA may have different abilities to regulate the pancreas (Hashimoto and Hara, 2004; Brake et al., 2014). In the studies of $\mathrm{Yu}$ et al. (2013) and Swanson et al. (2008), older animals were used (adult goats and 1-yr-old castrated cattle, respectively). Older animals may respond to the same AA differently than younger animals with respect to pancreatic enzyme secretion. Swanson et al. (2008) found that when 1-yr-old castrated cattle were fed diets that differed in CP level, the diet with a higher protein level increased the concentration of pancreatic enzymes, whereas the size of the pancreas was not affected.

Although the size of the pancreas can be used to evaluate pancreas development, it does not necessarily reflect the level of function of the pancreas and does not explain the reasons for the differences in function. The number and size of the pancreatic cells can be used to evaluate the effect of AA on pancreas development (Swanson et al., 2008). In this study, supplementation with phenylalanine alone increased the concentration of DNA in the pancreas and significantly decreased the protein:DNA ratio, suggesting that the number of pancreatic cells per unit of pancreatic weight was increased, but the cell size was decreased by phenylalanine supplementation. Intriguingly, no significant increase in the pancreatic enzyme activities accompanied the phenylalanine effect. This contradicts the results of Swanson et al. (2008) in yearling beef cattle and Yu et al. (2013) in adult goats, where they showed that the size, rather than the number, of the pancreatic cells affected the production ability of pancreatic digestive enzymes. This discrepancy may be attributed to the difference in the age of the animals used - that is, yearling cattle in Swanson et al. (2008), adult goats in Yu et al. (2013), and calves in this research. Conceivably, in growing ruminants that are still developing, phenylalanine may promote proliferation of pancreatic cells, whereas in adult ruminants phenylalanine can only increase the size of pancreatic cells. Leucine, alone and in combination with phenylalanine, tended to promote pancreatic protein per unit of $\mathrm{BW}$, indicating that leucine may increase the size of pancreatic cells in calves.

The regulation of pancreatic enzyme expression is very complex. The possible mechanisms may include changes in tissue weight, mRNA levels of digestive enzymes, concentrations of digestive enzymes, and digestive enzyme posttranslational modifications (Swanson et al., 2002). In our study, phenylalanine supplementation significantly increased the relative expression of the trypsin gene of the pancreas. Such upregulation of the trypsin gene might be due to the increased CCK level observed in the blood. This has been proposed previously (Yu et al., 2013), and CCK can indeed significantly stimulate the pancreas enzyme activities, and gene expression of trypsin is relatively sensitive to changes in the diet. Leucine has been shown to regulate the secretion of pancreatic insulin (Yang et al., 2015). In this study, both leucine and phenylalanine showed no significant effect on the activity and gene expression of pancreatic $\alpha$-amylase in calves, which is not consistent with the research results of Liu et al. (2015) in dairy cows and Yu et al. (2013, 2014) in adult dairy goats. Such discrepancy may be due to the differences in age of the animals and starch levels in the diets.

\section{CONCLUSIONS}

The results of this study show that supplementation with leucine or phenylalanine did not stimulate pancreatic $\alpha$-amylase, trypsin, or lipase activity in milk-fed calves, but both AA changed the growth of pancreatic cells. Leucine increased the size of individual pancreatic cells, and phenylalanine increased the total number of 
pancreatic cells. Phenylalanine increased circulating insulin and CCK, which may be an indication of pancreatic cell differentiation and function.

\section{ACKNOWLEDGMENTS}

The work was partially supported by the National Natural Science Foundation of China (award no. 31472122 and 31672451) and Collaborative Innovation Major Project of Industry, University, Research, and Application in Yangling Demonstration Zone (award no. 2016CXY-18).

\section{REFERENCES}

AOAC International. 1999. Official Methods of Analysis. 16th ed. Association of Analytical Chemists, Washington, DC.

Baile, C. A., Z. Glick, and J. Mayer. 1969. Effects of secretin and cholecystokinin-pancreozymin on pancreatic juice and insulin secretion of goats. J. Dairy Sci. 52:513-517.

Ballinger, A. B., and M. L. Clark. 1994. L-Phenylalanine releases cholecystokinin (CCK) and is associated with reduced food intake in humans - Evidence for a physiological role of CCK in control of eating. Metab. Clin. Exp. 43:735-738.

Boultwood, J., B. H. Yip, C. Vuppusetty, A. Pellagatti, and J. S. Wainscoat. 2013. Activation of the mTOR pathway by the amino acid L-leucine in the 5q-syndrome and other ribosomopathies. Adv. Biol. Regul. 53:8-17.

Brake, D. W., E. C. Titgemeyer, and D. E. Anderson. 2014. Duodenal supply of glutamate and casein both improve intestinal starch digestion in cattle but by apparently different mechanisms. J. Anim. Sci. 92:4057-4067.

Crozier, S. J., M. D. Sans, C. H. Lang, L. G. D'Alecy, S. A. Ernst, and J. A. Williams. 2008. CCK-induced pancreatic growth is not limited by mitogenic capacity in mice. Am. J. Physiol. Gastrointest. Liver Physiol. 294:G1148-G1157.

de Dios, I., M. A. Manso, and J. J. Calvo. 1988. Alterations of pancreatic juice amylase by glucocorticoid levels in the rat. Biochem. Med. Metab. Biol. 40:76-85.

Deckardt, K., A. Khol-Parisini, and Q. Zebeli. 2013. Peculiarities of enhancing resistant starch in ruminants using chemical methods: Opportunities and challenges. Nutrients 5:1970-1988.

Ensafi, A. A., E. Khoddami, and M. Jafari-Asl. 2015. A supported liquid membrane for microextraction of insulin, and its determination with a pencil graphite electrode modified with $\mathrm{RuO}_{2}$. Mikrochim. Acta 182:1599-1607.

Gressley, T. F., M. B. Hall, and L. Armentano. 2011. Ruminant Nutrition Symposium: Productivity, digestion, and health responses to hindgut acidosis in ruminants. J. Anim. Sci. 89:1120-1130.

Hara, H., T. Nishi, H. Narakino, and T. Kasai. 1996. CK-independent increases in pancreatic secretion induced by dietary protein in chronic BPJ-diverted rats. Am. J. Physiol. 271:G501-G508.

Harmon, D. L. 2009. Understanding starch utilization in the small intestine of cattle. Asian-australas. J. Anim. 22:915-922.

Harmon, D. L., R. M. Yamka, and N. A. Elam. 2004. Factors affecting intestinal starch digestion in ruminants: A review. Can. J. Anim. Sci. 84:309-318.

Hashimoto, N., and H. Hara. 2004. Dietary branched-chain amino acids suppress the expression of pancreatic amylase mRNA in rats. Biosci. Biotechnol. Biochem. 68:1067-1072.

Herrera-Saldana, R. E., J. T. Huber, and M. H. Poore. 1990. Dry matter, crude protein, and starch degradability of five cereal grains. J. Dairy Sci. 73:2386-2393.

Huntington, G. B. 1997. Starch utilization by ruminants: From basics to the bunk. J. Anim. Sci. 75:852-867.
Huntington, G. B., D. L. Harmon, and C. J. Richards. 2006. Sites, rates, and limits of starch digestion and glucose metabolism in growing cattle. J. Anim. Sci. 84(Suppl.):E14-E24.

Jiang, Z. E., C. Jiang, B. Chen, C. S. Koh, J. H. Yong, D. H. Park, M. H. Won, and Y. L. Lee. 2013. Age-associated changes in pancreatic exocrine secretion of the isolated perfused rat pancreas. Lab. Anim. Res. 29:19-26.

Kim, J., G. Song, G. Wu, H. Gao, G. A. Johnson, and F. W. Bazer. 2013. Arginine, leucine, and glutamine stimulate proliferation of porcine trophectoderm cells through the MTOR-RPS6K-RPS6EIF4EBP1 signal transduction pathway. Biol. Reprod. 88:113.

Liao, S. F., E. S. Vanzant, D. L. Harmon, K. R. McLeod, J. A. Boling, and J. C. Matthews. 2009. Ruminal and abomasal starch hydrolysate infusions selectively decrease the expression of cationic amino acid transporter mRNA by small intestinal epithelia of forage-fed beef steers. J. Dairy Sci. 92:1124-1135.

Liou, A. P., Y. Sei, X. L. Zhao, J. Y. Feng, X. P. Lu, C. Thomas, S. Pechhold, H. E. Raybould, and S. A. Wank. 2011. The extracellular calcium-sensing receptor is required for cholecystokinin secretion in response to L-phenylalanine in acutely isolated intestinal I cells. Am. J. Physiol. Gastrointest. Liver Physiol. 300:G538-G546.

Liu, K., Y. Liu, S. M. Liu, M. Xu, Z. P. Yu, X. Wang, Y. C. Cao, and J. H. Yao. 2015. Relationships between leucine and the pancreatic exocrine function for improving starch digestibility in ruminants. J. Dairy Sci. 98:2576-2582.

Livak, K. J., and T. D. Schmittgen. 2001. Analysis of relative gene expression data using real-time quantitative PCR and the $2^{-\triangle \Delta C T}$ method. Methods 25:402-408.

Murphy, J. A., D. N. Criddle, M. Sherwood, M. Chvanov, R. Mukherjee, E. McLaughlin, D. Booth, J. V. Gerasimenko, M. Raraty, and P. Ghaneh. 2008. Direct activation of cytosolic Ca2+ signaling and enzyme secretion by cholecystokinin in human pancreatic acinar cells. Gastroenterology 135:632-641.

Nilaweera, K. N., L. Giblin, and R. P. Ross. 2010. Nutrient regulation of enteroendocrine cellular activity linked to cholecystokinin gene expression and secretion. J. Physiol. Biochem. 66:85-92.

NRC. 2001. Nutrient Requirements of Dairy Cattle. 7th rev. ed. Natl. Acad. Press, Washington, DC.

Owens, F. N., R. A. Zinn, and Y. K. Kim. 1986. Limits to starch digestion in the ruminant small intestine. J. Anim. Sci. 63:1634-1648.

Owyang, C. 1994. Negative feedback control of exocrine pancreatic secretion: Role of cholecystokinin and cholinergic pathway. J. Nutr. 124(Suppl.):1321S-1326S.

Rachdi, L., V. Aiello, B. Duvillie, and R. Scharfmann. 2012. L-Leucine alters pancreatic beta-cell differentiation and function via the mTOR signaling pathway. Diabetes 61:409-417.

Rasmussen, H., K. C. Zawalich, S. Ganesan, R. Calle, and W. S. Zawalich. 1990. Physiology and pathophysiology of insulin secretion. Diabetes Care 13:655-666.

Richards, C. J., A. F. Branco, D. W. Bohnert, G. B. Huntington, M. Macari, and D. L. Harmon. 2002. Intestinal starch disappearance increased in steers abomasally infused with starch and protein. J. Anim. Sci. 80:3361-3368.

Rinderknecht, H., R. Maset, K. Collias, and C. Carmack. 1983. Pancreatic secretory profiles of protein, digestive, and lysosomal enzymes in Syrian golden hamster. Dig. Dis. Sci. 28:518-525.

Sadri, H., D. von Soosten, U. Meyer, J. Kluess, S. Dänicke, B. Saremi, and H. Sauerwein. 2017. Plasma amino acids and metabolic profiling of dairy cows in response to a bolus duodenal infusion of leucine. PLoS One 12:e0176647.

Sans, M. D., M. Tashiro, N. L. Vogel, S. R. Kimball, L. G. D'Alecy, and J. A. Williams. 2006. Leucine activates pancreatic translational machinery in rats and mice through mTOR independently of CCK and insulin. J. Nutr. 136:1792-1799.

Swanson, K. C., J. A. Benson, J. C. Matthews, and D. L. Harmon. 2004. Pancreatic exocrine secretion and plasma concentration of some gastrointestinal hormones in response to abomasal infusion of starch hydrolyzate and/or casein. J. Anim. Sci. 82:1781-1787.

Swanson, K. C., N. Kelly, H. Salim, Y. J. Wang, S. Holligan, M. Z. Fan, and B. W. McBride. 2008. Pancreatic mass, cellularity, and 
alpha-amylase and trypsin activity in feedlot steers fed diets differing in crude protein concentration. J. Anim. Sci. 86:909-915.

Swanson, K. C., J. C. Matthews, C. A. Woods, and D. L. Harmon. 2002. Postruminal administration of partially hydrolyzed starch and casein influences pancreatic alpha-amylase expression in calves. J. Nutr. 132:376-381.

Van Soest, P. J., J. B. Robertson, and B. A. Lewis. 1991. Methods for dietary fiber, neutral detergent fiber, and nonstarch polysaccharides in relation to animal nutrition. J. Dairy Sci. 74:3583-3597.

White, H. M., S. L. Koser, and S. S. Donkin. 2012. Gluconeogenic enzymes are differentially regulated by fatty acid cocktails in MadinDarby bovine kidney cells. J. Dairy Sci. 95:1249-1256.

Wu, G. 2010. Functional amino acids in growth, reproduction, and health. Adv. Nutr. 1:31-37.

Wu, G. 2013. Functional amino acids in nutrition and health. Amino Acids 45:407-411.

Xu, G., G. Kwon, W. S. Cruz, C. A. Marshall, and M. L. McDaniel. 2001. Metabolic regulation by leucine of translation initiation through the mTOR-signaling pathway by pancreatic beta-cells. Diabetes 50:353-360.
Yang, J., M. Dolinger, G. Ritaccio, D. Conti, X. Zhu, and Y. Huang. 2015. Leucine as a stimulant of insulin. Pages 49-62 in Branched Chain Amino Acids in Clinical Nutrition. R. Rajendram, V. R. Preedy, and V. B. Patel, ed. Humana, New York, NY.

Yu, Z. P., M. Xu, F. Wang, K. Liu, J. H. Yao, Z. Wu, D. K. Qin, and F. F. Sun. 2014. Effect of duodenal infusion of leucine and phenylalanine on intestinal enzyme activities and starch digestibility in goats. Livest. Sci. 162:134-140.

Yu, Z. P., M. Xu, J. H. Yao, K. Liu, F. Li, Y. Liu, F. Wang, F. F. Sun, and N. N. Liu. 2013. Regulation of pancreatic exocrine secretion in goats: Differential effects of short- and long-term duodenal phenylalanine treatment. J. Anim. Physiol. Anim. Nutr. (Berl.) 97:431-438

Zabielski, R., I. Le Huërou-Luron, and P. Guilloteau. 1999. Development of gastrointestinal and pancreatic functions in mammalians (mainly bovine and porcine species): Influence of age and ingested food. Reprod. Nutr. Dev. 39:5-26.

Zinn, R. A., F. N. Owens, and R. A. Ware. 2002. Flaking corn: Processing mechanics, quality standards, and impacts on energy availability and performance of feedlot cattle. J. Anim. Sci. 80:1145-1156. 